NISTIR 6891

\title{
Community-Scale Fire Spread
}

Ronald G. Rehm

Anthony Hamins

Howard R. Baum

Kevin B. McGrattan

David D. Evans 
NISTIR 6891

\section{Community-Scale Fire Spread}

Ronald G. Rehm

Anthony Hamins

Howard R. Baum

Kevin B. McGrattan

David D. Evans

Fire Research Division

Building and Fire Research Laboratory

July 2002

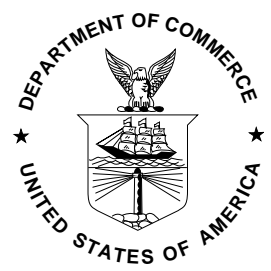

U.S. Department of Commerce Donald L. Evans, Secretary

National Institute of Standards and Technology Arden L. Bement, Director 


\title{
Community-Scale Fire Spread
}

Ronald G. Rehm, Anthony Hamins, Howard R. Baum, Kevin B. McGrattan, David D. Evans

Building and Fire Research Laboratory

National Institute of Standards and Technology (NIST)

Gaithersburg, Maryland, 20899, USA

\begin{abstract}
This paper addresses community-scale fires, which have also been called urban/wildland interface or intermix fires. These fires arise when wildland fires invade the built environment and attack structures as well as wildland fuels. The prediction of the spread of wildland fires, such as those occurring out West during the summer of 2000, has been accomplished through "operational" mathematical models. These models are based on empirical correlations for wildland fuels and have generally performed well. They fail, however, when the fire spreads to the built environment where the empirical correlations no longer apply and where there is greatly increased potential for property damage, injury and death. The Oakland and Berkeley Hills fire of October 21, 1991, and the Los Alamos fires of May 2000 are examples of community-scale fires. The potential fuel loadings for various land uses demonstrates that structures generally provide much higher loadings than wildlands do. While this comparison is useful, it could also be misleading since generally, not all of the potential fuel in either the wildland or the built environment will burn. Furthermore, often the time scales for ignition and the heat release rates for the wildland fuel and the fuel in the structures will be widely disparate, and these differences will influence both the spread rate of the fire and its persistence. Although the NIST computational model known as the Fire Dynamic Simulator (FDS) was developed to study building fires, it is now being extended to study community-scale fires. These extensions require much higher resolution data on local topography, buildings, vegetation, and meteorological conditions. They also require additional research on the mechanisms by which fires spread in the built environment between discrete elements, such as structures or structures and trees.
\end{abstract}

This paper appeared as pp 126-139 in:

Blonski, K.S., M.E. Morales and T.J. Morales, 2002. Proceedings of the California's 2001 Wildfire Conference: Ten Years After the 1991 East Bay Hills Fire, 10-12 October 2001, Oakland California Technical Report 35.01.462. Richmond CA; University of California Forest Products Laboratory.

\section{Published by:}

University of California Agriculture \& Natural Resources, Forest Products Laboratory, 1301 South 46th Street, Richmond CA 94804, www.ucfpl.ucop.edu. 


\title{
COMMUNITY-SCALE FIRE SPREAD
}

\section{ABSTRACT}

\author{
R.G. Rehm, A. Hamins, H.R. Baum, \\ K.B. Mcgrattan and D.D. Evans, \\ Building and Fire Research Laboratory, \\ National Institute of Standards \& Technology, \\ Gaithersburg, MD 28099 \\ Email: Ronald.Rehm@nist.gov
}

This paper addresses community-scale fires, which have also been called urban/wildland interface or intermix fires. These fires arise when wildland fires invade the built environment and attack structures as well as wildland fuels. The prediction of the spread of wildland fires, such as those occurring out West during the summer of 2000, has been accomplished through "operational" mathematical models. These models are based on empirical correlations for wildland fuels and have generally performed well. They fail, however, when the fire spreads to the built environment where the empirical correlations no longer apply and where there is greatly increased potential for property damage, injury and death. The Oakland and Berkeley Hills fire of October 21, 1991, and the Los Alamos fires of May 2000 are examples of community-scale fires. The potential fuel loadings for various land uses demonstrates that structures generally provide much higher loadings than wildlands do. While this comparison is useful, it could also be misleading since generally, not all of the potential fuel in either the wildland or the built environment will burn. Furthermore, often the time scales for ignition and the heat release rates for the wildland fuel and the fuel in the structures will be widely disparate, and these differences will influence both the spread rate of the fire and its persistence. Although the NIST computational model known as the Fire Dynamic Simulator (FDS) was developed to study building fires, it is now being extended to study community-scale fires. These extensions require much higher resolution data on local topography, buildings, vegetation, and meteorological conditions. They also require additional research on the mechanisms by which fires spread in the built environment between discrete elements, such as structures or structures and trees.

Keywords: Wildland/Urban Interface Fires; Mathematical Models; Computational Fluid Dynamics; Potential Fuel Loads;

\section{INTRODUCTION}

Fires in the West have been headlines in the news for most of the summer of 2000. Changes in the management of forested lands, the increasing intrusion of man into more remote areas and the cyclic dry periods produced by El Nino - La Nina have all increased the destruction of manmade structures by fires. Wildland fires now often spread into the built environment causing injury, death and property damage. Concern about wildland fires and their effects on man and the built environment has produced several recent conferences Livingston (2000), Keller (2000), Platt (2000). While these conferences acknowledge the need to address fire spread in a mixed environment containing both structures and wildland fuels, i.e., community-scale fires, they have continued to focus 
on wildland fires where understanding and predictive models of the fire spread are well developed.

Compared with wildland fires, those which impact the built environment are generally more costly, both in terms of loss of life and injury and also in terms of property damage. What characterizes fires in the built environment and how do they differ from wildland fires? By comparing and contrasting community fires and wildland fires, we hope to characterize conceptual differences between the two. Then, we suggest research areas needed to develop a mathematical model to describe fire spread in the built environment, where both individual structures and wildland fuels trees, shrubs and ground litter - compose the fuel inventory.

Note first that the manner in which the fires are fought differs dramatically. Most communities have either professional or volunteer fire departments, which usually respond to individual structure fires in the built environment. Wildland fires, on the other hand, usually occur in federal or state owned land and are therefore the responsibility of one or more government agencies. Both the training and the response of community fire departments are very different from units trained to fight wildland fires, and only in a few locations are firefighters given cross training to fight both types of fires. Furthermore, the scientific communities which study each type of fire and the corresponding literatures are almost disjoint.

In 1998 there were 1.75 million responses by local fire departments, with about a half million being structures (others involving vehicles, materials outside of structures, etc.) Karter (1999). Over 4000 civilian deaths and 17,000 injuries occurred as a result of these fires, and the cost of the fires was about $\$ 8.6$ billion. Significantly, the number of fires in various categories together with associated losses have either remained the same or decreased since 1977, the first year that the NFPA (National Fire Protection Administration) conducted its survey using current methodology.

In contrast, in the West during the summer of 2000, there were about 80,000 fires, which destroyed about 7 million acres and required about $\$ 1$ billion in Federal funds for suppression costs. Expectations are that future wildland fires will continue at rates more like the summer of 2000 than those in recent summers past. The federal agencies responsible for control of these fires reside in the Department of Interior (DOI) and the Department of Agriculture. They are the National Park Service, the U.S. Geological Survey, the Bureau of Land Management, the Fish and Wildlife Service and the Bureau of Indian Affairs, all part of the DOI, and the Forest Service which is part of Agriculture.

The acreage of wildland destroyed by fires has undergone considerable variation during the twentieth century, and this variation has lead to substantial changes in forest management strategies. Recently for example, fires in wooded areas have begun to be viewed in much more ambivalent terms; it has been recognized that smaller and more frequent fires can clean out debris, thin woods and make them healthier and more resistant to large, catastrophic fires. The so-called "prescribed burn" has now become a tool by which wildlands are managed.

In the next section, we characterize the fuel load by land use. First, a brief review of the literature on the characterization of wildland fuels is presented. Then, we look at the corresponding literature concerning structural fires. In each case the emphasis is on the potential fuel loadings 
available for burning in various settings. In the third section, we examine differences arising from attempts to mathematically model each type of fire. A brief discussion of wind-driven fire spread models in wildlands is presented, since these models are relatively well developed. Furthermore, they have been used extensively for research, training, planning (for prescribed fires for example), and to provide real-time emergency-response predictions to guide fire fighting operations. The corresponding models are not available for multiple-structure community fires. Finally, we discuss extensions to a computational model developed by NIST which could be used to address the problem of predicting community-scale fire spread in areas containing both vegetation and structures (the so-called urban-wildland intermix).

\section{POTENTIAL FUEL LOADINGS}

The most basic characterization of land use relative to fire is the amount of fuel available on the land. Specifically, the potential fuel energy loading per unit area is a useful measure which allows a direct comparison between fuels in wildland settings and those in man-made structures. While this comparison is useful, it could also be misleading since generally, not all of the potential fuel in either the wildland or the built environment will burn. Furthermore, often the time scales for ignition and the heat release rates for the wildland fuel and the fuel in the man-made structures will be widely disparate, and these differences will influence both the spread rate of the fire and its persistence.

\section{Wildland Fuels}

Fuel characterization and fire behavior in wildlands is the subject of several books: Pyne et al (1996), Chandler et al (1983a), Chandler et al (1983b), Brown and Davis (1973) and Luke and McArthur (1973).

Chandler et al (1983a) describe the total amount of plant material, both living and dead, but excluding roots and animal matter as phytomass. They state that the total phytomass on any site has a physiological upper limit: $W=23 \sqrt{A}=(26 \sqrt{A})$, where $W$ is the total phytomass in newtons $/ m^{2}$ (tons per hectare) and $A$ is the stand age in years. The degree to which this limit is approached depends on the site quality, but is not dependent on the particular vegetation. Potential fuel loading is the maximum fuel available, or the amount of material that could be consumed in the most intense fire. Available fuel loading is the amount of fuel that is expected to burn under specified fire weather conditions, and is therefore widely used for planning prescribed fires where weather conditions are known in advance. Usually, foliage and small crown material (branches and twigs of $5 \mathrm{~cm}$ ( 2 inch) diameter or less) is what burns in tree crown fires.

Wildfires have been characterized in terms of 13 standard fire behavior fuel models, whose properties are tabulated by Pyne et al (1996). All fuel loads are given in terms of fuel mass per area (tons/acre), with a footnote stating that, for all fuel models, the energy content per mass is 18.6 MegaJoules (MJ)/kg (8000 Btu/lb). The data for fuel loadings are restated in Table 1, first in units of kilograms per hectare, and then, in GigaJoules (GJ) per hectare.

Wildland fuels are composed mostly of lignin and cellulose in both living (green) and dead 
forms and vary widely in distribution, physical characteristics and their effect on fire behavior. Chandler et al (1983a) give the composition, heat of combustion, and moisture content of living tree material. This information plus the composition and heat of combustion for "an average tree" are presented in Table 2 below. From this chart, we infer that average wildland fuels yield about $15-20 \mathrm{MJ} / \mathrm{kg}$, a value consistent with that stated above by Pyne et al (1996).

Dry fuel characteristics for individual conifers can also be inferred from data in the NIST Report by D.W. Stroup et al. (1999) in which eight scotch pines were separately burned. Measurements included weight before and after each burn, height and width of each tree and moisture content before the test. During each burn, the oxygen consumption rate was inferred from captured combustion gases. The oxygen consumption can be related to the heat release rate (HRR), using a factor which is approximately constant for all fuels (oxygen calorimetry). The mass loss determines the total energy released, and agrees approximately with the integral of the HRR with respect to time. The initial mass of these trees ranged between $9.5 \mathrm{~kg}$ to $28.1 \mathrm{~kg}$, and the energy per unit mass for complete consumption of these partially dried conifers was found to be about 17 $\mathrm{MJ} / \mathrm{kg}$, again confirming the values stated above.

\begin{tabular}{|c|c|c|c|}
\hline \hline No. & $\begin{array}{c}\text { Fuel } \\
\text { Complex }\end{array}$ & $\begin{array}{c}\text { Load } \\
\text { kg/hectare }\end{array}$ & $\begin{array}{c}\text { Energy Load } \\
\text { GJ/hectare }\end{array}$ \\
\hline \hline & Grass \& grass dominated & & \\
1 & Short grass & 1660 & 32 \\
2 & Timber (grass\& understory) & $1100-4400$ & $21-84$ \\
3 & Tall grass & 6700 & 124 \\
\hline & Chaparral \& Shrubs & & \\
4 & Chaparral & $4400-11000$ & $84-207$ \\
5 & Brush & $1100-2200$ & $21-42$ \\
6 & Dormant brush, wood slash & $3500-5700$ & $62-104$ \\
7 & Southern rough & $2400-4200$ & $47-79$ \\
\hline & Timber litter & & \\
8 & Closed timber litter & $2400-5700$ & $42-104$ \\
9 & Hardwood litter & $350-6400$ & $6.2-120$ \\
10 & Timber (litter \& understory) & $4400-11000$ & $84-210$ \\
\hline & Slash & $3500-12400$ & $62-230$ \\
11 & Light logging slash & $8900-37000$ & $168-690$ \\
12 & Medium logging slash & $16000-62000$ & $300-1100$ \\
\hline 13 & Heavy logging slash &
\end{tabular}

Table 1: Potential mass and energy loading for the 13 standard fuel models, from Pyne et al. (1996). 


\begin{tabular}{|c|c|c|c|c|}
\hline \hline Living Tree Fuel & $\begin{array}{c}H_{c} \\
\mathrm{~J} / \mathrm{g}\end{array}$ & $\begin{array}{c}\text { Dry Weight } \\
\text { Composition }\end{array}$ & $\begin{array}{c}\text { Ave. Tree } \\
\text { Dry Weight }\end{array}$ & $\begin{array}{c}<H_{c}> \\
\mathrm{J} / \mathrm{g}\end{array}$ \\
\hline \hline $\begin{array}{c}\text { Cellulose } \\
\text { Hemicelluloses }\end{array}$ & 16170 & $50-75 \%$ & $65 \%$ & 10500 \\
\hline Lignin & 24612 & $15-35 \%$ & $25 \%$ & 6200 \\
\hline Extractives & 32424 & $.2-15 \%$ & $5 \%$ & 1600 \\
\hline Mineral & 0 & $5-10 \%$ & $5 \%$ & 0 \\
\hline Total & & & & 18000 \\
\hline \hline $\begin{array}{c}\text { Moisture } \\
\text { (foliage,twigs) }\end{array}$ & 2400 & $100-250 \%$ & $150 \%$ & -3600 \\
\hline \hline
\end{tabular}

Table 2: Living tree fuel composition: in the first two columns are shown the heat of combustion and the dry weight percentage range by component. (The last two rows show the heat of evaporation and the moisture content range.) Values are taken from Chandler et al. (1983). The last two columns display for an "average tree," a dry weight composition and the corresponding heat of combustion, with the moisture content and the heat of vaporization for this "average tree" being given in the last row.

\section{Fuel Loading from Structures}

Burning man-made fuels and fires in enclosures are the subject of books by Drysdale (1985) and Quintiere (1998). In addition, a review by Pitts (1991). deals with wind effects on urban mass fires.

In the suburban and urban setting, the key quantity is the density of houses - together with the combustible material in these houses - in determining fuel loading and fire behavior. The density of trees, shrubs and ground cover (grass) may still be important for determination of the fire behavior, but clearly house density is critical.

An estimate of the energy release rate during a house fire in the Oakland and Berkeley Hills fires was made by Trelles (1995) and by Trelles and Pagni (1997). According to these estimates, a house burns at a peak rate of $45 \mathrm{MW}$ for $1 \mathrm{~h}$ (yielding about $160 \mathrm{GJ}$ ), and then dies down over another $6 \mathrm{~h}$ period. The die-down of the fire is approximated as two steps, one $10 \mathrm{MW}$ for $3 \mathrm{~h}$ and the last as $5 \mathrm{MW}$ for 3 more $\mathrm{h}$. The total burn time is $7 \mathrm{~h}$, and the total energy released by the house is 324 GJ. If, as assumed also, there is brush around each house which releases another $5 \mathrm{MW}$ for one $\mathrm{h}$, then an additional $18 \mathrm{GJ}$ of energy will be released. If the house is assumed to be $15 \mathrm{~m}$ by 15 $\mathrm{m}$ by $5 \mathrm{~m}$, then we estimate the total potential fuel loading per unit area to be of order $1.44 \mathrm{GJ} / \mathrm{m}^{2}$, the peak HRR per unit area to be of order $0.2 \mathrm{MW} / \mathrm{m}^{2}$, and the volumetric heat release rate to be of order $0.04 \mathrm{MW} / \mathrm{m}^{3}$. For comparison, oil has an energy content of about $42 \mathrm{MJ} / \mathrm{kg}$, and oil pool fires yield a heat release rate per unit area of approximately $2 \mathrm{MW} / \mathrm{m}^{2}$, see McGrattan et al. (1996), Baum et al. (1994) and Baum (1999). Furthermore, Chandler et al (1983b) describe the concept of an "ideal" burning rate, which was first introduced by Tewarson and Pion (1976), and they tabulate the ideal burning rates for several fuels. Liquid hydrocarbons have ideal heat release rates per unit 
area ranging between 0.7 and $3.0 \mathrm{MW} / \mathrm{m}^{2}$. The corresponding rate for wood is about $0.26 \mathrm{MW} / \mathrm{m}^{2}$.

\section{Wildland and Urban Fuel Loading}

The only reference of which we are aware that discusses technical issues related to wildland and community fires is Chapter 8 of Chandler et al. (1983b). entitled, "Fire at the Urban-Forest Interface." This chapter makes several very important observations. First, the authors note that fuel loadings in buildings are typically many times those in a forest: "the heaviest likely fuel load in the forest is less than the lightest load for a structure." Next they observe that fuels in buildings include a variety of combustibles whereas forest fuels are exclusively cellulosic. The authors also point out several important differences between burning in a structure and burning forest fuels. Moisture, which is very important during burning, is controlled within a building, but is determined in wildlands by environmental factors such as the sun, wind and precipitation. Radiation from an indoor fire is trapped inside the building whereas most radiation in a wildland fire escapes. Similarly, most convective heat is trapped in an indoor fire whereas it is lofted into the atmosphere in a wildland fire. Finally, oxygen is severely limited in an indoor fire whereas it is virtually unlimited in a wildland fire.

The first point concerning the potential fuel loading differences between structural fires and wildland fires is illustrated in Table 8.1 of Chapter 8 of Chandler et al. (1983b). This table shows the land use (or area) in one column and the corresponding mass loading of fuel in the second; it is reproduced below with the addition of columns showing the potential mass load in kilograms per acre and the corresponding potential energy load in GJ per hectare. (Some of the numbers in this table appear large compared to those reported here and elsewhere.)

\begin{tabular}{|c|c|c|c|}
\hline \hline Area & Fuel Type & $\mathrm{kg} / \mathrm{hectare}$ & $\begin{array}{c}\text { Fuel Load/hectare } \\
\text { (GJ/hectare) }\end{array}$ \\
\hline \hline Forest & Grass \& sward (Tasmania) & 4900 & 94 \\
Forest & Heavy brush (Southern Cal.) & 101,000 & 1680 \\
Forest & Maximum & $27,000 \times \sqrt{A}$ & $490 \times \sqrt{A}$ \\
\hline \hline Urban & Dwellings, offices, schools & $202,000-504,000$ & $3700-9400$ \\
Urban & Apartments & $490,000 \times N$ & $8900 \times N$ \\
Urban & Shops & $500,000-1,010,000$ & $9400-18800$ \\
Urban & Industrial \& storage & $300,000-3,000,000$ or more & $5,700-57,000$ or more \\
\hline \hline
\end{tabular}

Table 3: Available Fuel Load (from "Fire at the Urban-Forest Interface," Chapter 8, Volume II, Chandler et al. (1983). Here $A$ is the age of the forest in years and $N$ is the number of floors in a multistory building.

Finally, the data from the past sections and the chart above are combined in Table 4, where the description of land use is presented with likely numbers of trees and houses per hectare. We have divided the description of the land use into four basic categories: wildland, rural, suburban and urban; and the wildland and rural categories have been further subdivided. This information can 
also be plotted as shown in Figure 1. In this figure, the number of structures per hectare is plotted as the abscissa and the ratio of the vegetation energy load to the structure energy load is the ordinate. In this diagram, wildland covers the upper left corner of the diagram, where the number of structures is small and the vegetation energy load is relatively high, whereas the urban area occupies the lower right corner. Also shown on this plot are several fires for which we estimated, from information available, the potential energy load per hectare where the fires did their greatest damage to the built environment, whether the fires began there or elsewhere. Note that the Oakland Hills Fire of 1991 and the Los Alamos/Cerro Grande Fire of 2000, fall directly in the category of suburban fires and are good examples of community-scale or urban-wildland interface fires.

\begin{tabular}{|c|c|c|c|c|}
\hline \hline Description & $\begin{array}{c}\text { Tree Density } \\
\text { (Trees/ hectare) }\end{array}$ & $\begin{array}{c}\text { House Density } \\
\text { (Houses/hectare) }\end{array}$ & $\begin{array}{c}\text { Tree Fuel Load } \\
\text { GJ/hectare }\end{array}$ & $\begin{array}{c}\text { House Fuel Load } \\
\text { GJ/hectare }\end{array}$ \\
\hline \hline $\begin{array}{c}\text { Wildland } \\
\text { Unhealthy Forest }\end{array}$ & $\begin{array}{c}740-2200 \\
\text { Nelson (2000) }\end{array}$ & 0 & $37-111$ & 0 \\
\hline $\begin{array}{c}\text { Wildland } \\
\text { Healthy Forest }\end{array}$ & $\begin{array}{c}49-124 \text { Ponderosa } \\
\text { Pines Nelson (2000) }\end{array}$ & 0 & $2.5-6.2$ & 0 \\
\hline \hline $\begin{array}{c}\text { Rural Area } \\
0-0.03 \text { people/acre }\end{array}$ & $0-74$ & $0-0.05$ & $0-3.7$ & $0-16$ \\
\hline Grass \& Brush & $0-25$ & $0-0.05$ & $0-0.12$ & $0-16$ \\
\hline Forested & $25-74$ & $0-0.05$ & $0.12-3.7$ & $0-16$. \\
\hline \hline Suburban Area & $25-74$ & $2.5-9.9$ & $1.2-3.7$ & $815-3200$ \\
\hline \hline Urban Area & $\approx 0$ & $37-$ or more & 0 & 12,000 or more \\
\hline \hline
\end{tabular}

Table 4: Land use described by tree and housing density (units/hectare).

\section{MODELING FIRE SPREAD}

\section{Wildland Fires}

The types of wildfires, their spread rates and intensities were summarized in a review article by Albini (1984) and are presented in Table 5. The wildfire types are ground fires (which burn or smolder in the subsurface organic material at a very slow rate), surface fires (which are most common and variable, and which burn in the material on the ground surface, such as debris, grass or chaparral) and crown fires (which are relatively rare, but spectacular and highly dangerous). An additional column has been added to this table to show the energy density of the consumed fuel, which can be determined from the numbers given in by Albini: if $I$ is the intensity of the fire, and $v$ is the spread rate, then the energy density $E=I / v$. 


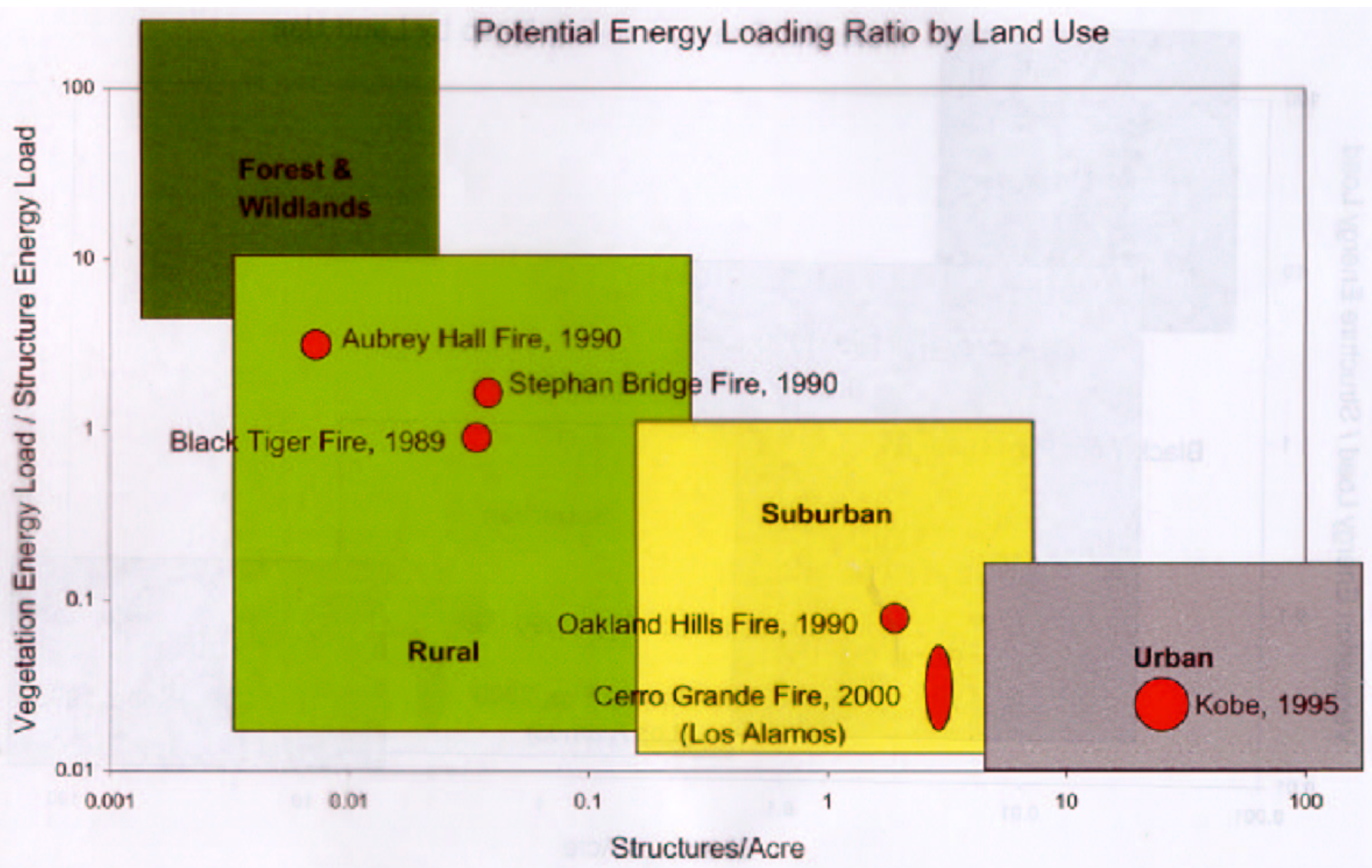

Figure 1: Potential energy loading by land use. Also shown are six specific fires including the Oakland Hills fire of 1991 and the Los Alamos/Cerro Grande fire of 2000.

\begin{tabular}{|l|c|c|c|c|}
\hline \hline Types of Wildfire & $\begin{array}{c}\text { Spread Rate } \\
(\mathrm{m} / \mathrm{h})\end{array}$ & $\begin{array}{c}\text { ROS } \\
(\mathrm{m} / \mathrm{s})\end{array}$ & $\begin{array}{c}\text { Intensity } \\
(\mathrm{MW} / \mathrm{m})\end{array}$ & $\begin{array}{c}\text { Fuel Energy Density } \\
(\mathrm{GJ} / \mathrm{hectare})\end{array}$ \\
\hline \hline Ground Fire & $0.00003 \mathrm{~m} / \mathrm{hr}$ & .0000083 & 0.00001 & 12 \\
\hline \hline Surface Fires & & & & 3.7 \\
\hline Marginal Conditions & 0.01 & 0.003 & 1 & 36 \\
\hline "Good" Conditions & 10 & 2.77 & 10 & 1.8 \\
\hline Grass Fires & 20 & 5.54 & 1 & 370 \\
\hline Debris Fires & 1 & 0.277 & 10 & 121 \\
\hline \hline Crown Fires & 3 & 0.833 & 10 & \\
\hline \hline
\end{tabular}

Table 5: Types of Wildfires, Rate of Spread (ROS) and Intensities as reported by Albini (1984). Also shown are fuel energy density implied by these values.

Fuel moisture and continuity are primary factors in the behavior of wildfires and in the difficulty of bringing them under control. Other fuel properties described by Chandler et al. (1983a) and by Pyne et al. (1996), which influence fire spread, are size and shape distribution, compactness and arrangement of the fuel. Wind conditions and topography are non-fuel-related factors 
which also influence fire spread. Finally, spotting or branding of a fire is yet another factor which influences its spread Albini (1981), Albini (1983), Woycheese and Pagni (1999) and Woycheese et al. (1999). (Spotting or branding is airborn burning debris lofted by the fire and carried by both ambient and fire-induced winds to locations separate and often remote from the main flaming region; these brands generally ignite additional fires in the new locations.)

For wildland fires, mathematical models are regularly used to predict the likely burn development for expected meteorological conditions. These models, which are known as operational models, have largely developed through empirical correlations over the past few decades. In the United States, they include the Rothermel model, Rothermel (1972), and models known as BEHAVE, Andrews and Bevins (1999), and FARSITE, Finney and Andrews (1999), with the last one being the most recent and most highly developed.

Generally, these operational models have served well as long as the fires are confined to wildlands. They are based on the assumption that the fuels can be represented by continuum beds, which may be inhomogeneous and anisotropic, but nevertheless are continuous. They fail, however, when conditions lie outside of those for which the empirical relations were developed, such as when fires become very intense and induce significant buoyant plumes with resulting atmospheric convection, Clark (1996).

\section{Fire Spread in the Built Environment}

These operational models regard the meteorological conditions as prescribed, and have not considered the winds generated by the fire itself. However, for large fires, the self-generated winds may be significant and can even dominate the fire-spread behavior Clark (1996), Baum (2000). Furthermore, to our knowledge, the only studies to consider the discrete nature of fuel elements are the study by Carrier et al. (1991), which examined the effects of discrete fuel elements in a wildland fire, and the study by Himoto and Tanaka (1997), which examined fire spread by radiation between structures in an urban setting.

When the built environment becomes involved, as in the Oakland and Berkeley Hills fire of October 21, 1991, or more recently the Los Alamos fires of May 2000, these models are totally ineffective. They cannot predict the spread of fire because the building fuel loads are larger and discrete. In these community-scale fires, buildings, as well as large individual trees, must be regarded as discrete fuel elements. At a fundamental level, the physical mechanisms controlling fire spread are very different than those in wildland fires. The empirical correlations upon which the wildland-fire models have been developed are no longer valid. No validated predictive models of fires in an urban or urban/wildland setting exist to our knowledge.

The NIST computational code, known as the Fire Dynamics Simulator (FDS), was originally developed to predict fire spread within buildings. Over the past few years, it has also been used to predict smoke and hot gas plume behavior produced by outdoor fires. In addition, more recently, it has been used to predict wind fields in the built environment with one to ten meter resolution over regions measuring up to one kilometer or so on a side. All of these simulations require only a current high-end PC running overnight. The code can be downloaded free from the URL: 
http://fire.nist.gov. It consists of two components, a computational fluid dynamics (CFD) code, called fds, written in Fortran 90 for computation of fire-driven flows, and an OpenGL graphics program known as smokeview for visualization of results, see McGrattan et al. (2000), McGrattan and Forney (2000), and Forney and McGrattan (2000).

The model has now been applied to several specific sites, including the NIST campus and individual plots of land in a small community, each of which includes at least one structure and many trees. At this time, the trees participate in the flow dynamics by providing wind resistance to the ambient or fire-driven flows, see Rehm et al. (2000); however, there is no submodel yet for tree burning in these simulations. The combustion is calculated using a mixture-fraction formulation, and radiation transport is also included, see McGrattan et al. (2000). In the simulation, brands, shown as black spots, are produced and carried by the wind in a dynamically simple, but correct manner. However, at present, there is no mechanism for the brands to ignite combustible material downstream of the fire.

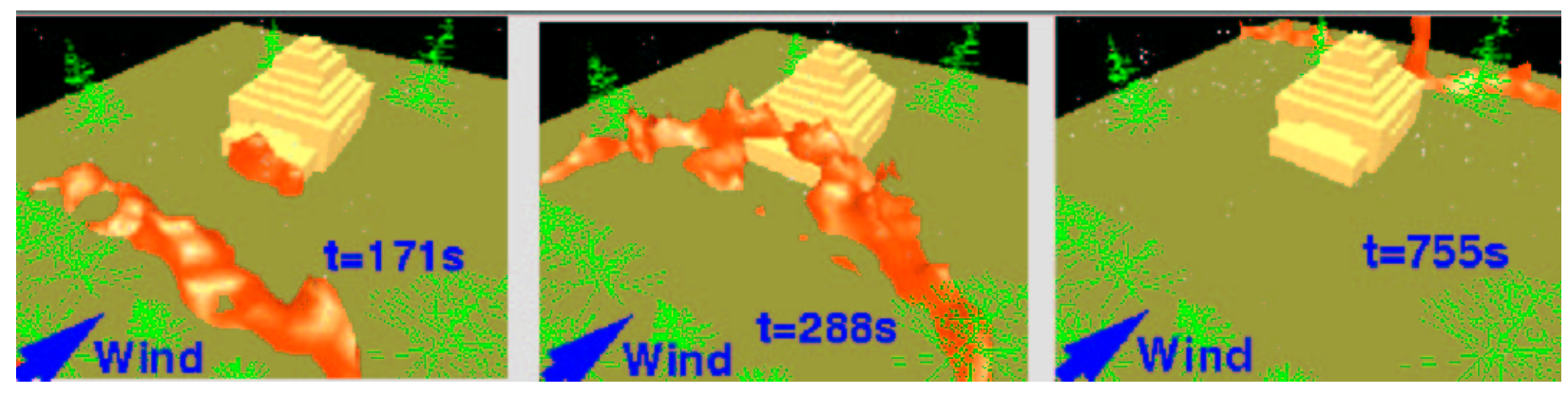

Figure 2: Three frames of a simulation of fire spread on a parcel of land containing a house, trees and dry grasses. These frames are taken at different times during the fire progression, and are qualitatively correct if the fire spread is primarily along the ground material. As noted in the body of this paper, several submodels must still be developed, tested experimentally and incorporated into these simulations. It is extremely important to note that the overall model must be able to describe the progression of a fire among discrete fuel elements, structures, trees and shrubs.

Figure 2 shows a composite of three frames from a simulation of wind-blown fire spread on a parcel of land on which there is a structure and wildland fuels (trees and dry grass). In this simulation, the fire (shown as red "flames") begins upwind of the building and progresses as a ground-fire toward the structure. The trees modify the incoming wind profile by providing drag, but, as noted above, the trees do not burn. The porch of the house is assumed to be made of easily ignitable material, while the house is not. Therefore, the porch, but not the house ignites. Submodels are still needed for burning of an individual tree, brand disributions produced by a tree or by a house, and brand spotting or ignition of downwind materials. All of these submodels must also be calibrated and validated through laboratory experiments, and probably later by limited full-scale burns.

Through these simulations, we are beginning to develop an understanding of the mechanisms by which fires progress in a community where both structures and wildland fuels coexist. Such 
an understanding will lead to a predictive capability using a model such as the one presented here. Propagation of fire by radiation, natural and fire-induced winds, brands and ground spread must all be examined both theoretically and experimentally to develop a verifiable predictive capability.

\section{LITERATURE CITED}

Albini, Frank A. 1984. Wildland Fires, American Scientist 590-597.

Albini, Frank A. 1985. A Model for Fire Spread in Wildland Fuels by Radiation. Combust. Sci. and Tech. 42:229-258.

Albini, Frank A. 1986. Wildland Fire Spread by Radiation - A Model Including Fuel Cooling by Natural Convection. Combust. Sci. and Tech. 45:101-113.

Albini, Frank A. and Brian J. Stocks. 1986. Predicted and Observed Rates of Spread of Crown Fires in Immature Jack Pine. Combust. Sci. and Tech. 48:65-76.

Albini, Frank A. 1997. An Overview of Research on Wildland Fire. Proceedings of the Fifth International Symposium on Fire Safety Science, Yuji Hasemi, editor.

Albini, F.A.. 1983. Transport of Firebrands by Line Thermals. Comb. Sci. \& Tech. 32:277288.

Albini, F.A.. 1981. Spot Fire Distance from Isolated Sources - Extensions of a Predictive Model. Research Note INT-309, Dept. of Agriculture, Forest Service, Intermountain Forest and Range Experiment Station.

Andrews, P.L., and C.D. Bevins. 1999. BEHAVE Fire Modeling System: Redesign and Expansion. Fire Management Notes. 59:16-19; Web site: http://fire.org/.

Baum, H.R., K.B. McGrattan and R.G. Rehm. 1994. Simulation of Smoke Plumes from Large Oil Fires. Twenty-Fifth Symposium (International) on Combustion, The Combustion Institute 25:1463-1469.

Baum, H.R. 2000. Large Eddy Simulations of Fire - from Concept to Computations. Fire Protection Engineering 6:36-42.

Baum, H.R. 2000. Modeling and Scaling Laws for Large Fires. Proceedings of ISSM-III, Third International Symposium on Scale Modeling, Nagoya, Japan.

Baum, H.R., K.B. McGrattan and R.G. Rehm. 1994. athematical Modeling and Computer Simulation of Fire Phenomena. Theoretical and Computational Fluid Dynamics 6:125-139.

Brown, Arthur A. and Kenneth P. Davis. 1973. Forest Fire Control and Use, second edition, 
McGraw-Hill Book Company, New York.

Carrier, G.F., F.E. Fendell, and M.F. Wolff. 1991. Wind-Aided Firespread across Arrays of Discrete Fuel Elements. I. Theory. Combust. Sci. and Tech. 75:31-51.

Chandler, Craig, Philip Cheney, Philip Thomas, Louis Trabaud and Dave Williams. 1983. Fire in Forestry: Volume I Forest Fire Behavior and Effects, Wiley-Interscience, John Wiley and Sons, New York.

Chandler, Craig, Philip Cheney, Philip Thomas, Louis Trabaud and Dave Williams. 1983. Fire in Forestry: Volume II Forest Fire Management, Wiley-Interscience, John Wiley and Sons, New York.

Clark, T.L., M.A. Jenkins, J. Coen and D. Packham. 1996. A Coupled Atmospheric-Fire Model: Convective Feedback on Fire-line Dynamics. J. Applied Meteorology 35:875-901.

Drysdale, Dougal. 1985. An Introduction to Fire Dynamics, Wiley-Interscience Publications, John Wiley and Sons, New York.

De Mestre, N.J., Catchpole, E.A., Anderson, D.H. and Rothermel, R.C. 1989. Uniform Propagation of a Planar Fire Front Without Wind. Combust. Sci. and Tech. 65:231-244.

Emmons, Howard. 1963. Fire in the Forest. Fire Research Abstracts and Reviews 5:163-178.

Finney, M.A. and P.L. Andrews. 1999. FARSITE - A Program for Fire Growth Simulation. Fire Management Notes. 59:13-15; Web site: http://fire.org/.

Forney, G.P. and K.B. McGrattan. 2000. User's Guide for Smokeview Version 1.0 - A Tool for Visualizing Fire Dynamics Simulation Data. NISTIR 6513, National Institute of Standards and Technology.

Himoto, K. and T. Tanaka. A Preliminary Model for Urban Fire Spread - Building Fire Behavior under the Influence of External Heat and Wind. Proceedings of

Karter, Michael J. 1999. 1998 Fire Loss in the United States. NFPA Journal.

Keller, C., Organizer. 2000. Integrating Research on Wildland Fuels and Fires. Los Alamos, New Mexico.

Livingston, R., Organizer, 2000. Second USGS Fire Science Workshop. Los Alamos, New Mexico.

Luke, R. Harry and A.G. McArthur. 1978. Bushfires in Australia. Australian Government Publishing Service, Canberra. 
McGrattan, K.B., H.R. Baum and R.G. Rehm, 1996. Numerical Simulation of Smoke Plumes from Large Oil Fires. Atmospheric Environment 30:4125-4136.

McGrattan, K.B., H.R. Baum, R.G. Rehm, A. Hamins and G.P. Forney. 2000. Fire Dynamics Simulator - Technical Reference Manual. Nist Report NISTIR 6467, National Institute of Standards and Technology.

McGrattan, K.B. and G.P. Forney. 2000. Fire Dynamics Simulator - User's Manual. Nist Report NISTIR 6469, National Institute of Standards and Technology.

Nelson, Robert H. 2000. Fires by Design. August 8 Washington Post.

Perry, G.L.W. 1998. Current Approaches to Modelling the Spread of Wildland Fire: a Review. Progress in Physical Geography. 22:222-245.

Pitts, W.M. 1991. Wind Effects on Fires. Prog. Energy Combust. Sci. 17:83-134.

Platt, R., Roundtable Chair 200. Natural Disasters Roundtable, Forum on Urban/Wildland Fire. 26 January, National Academy of Sciences. Washington, D.C.

Pyne, Stephen J., Patricia L. Andrew and Richard D. Laven, , 1996. Introduction to Wildland Fire, second edition, John Wiley \& Sons, Inc. New York.

Quintiere, James G. 1993. Canadian Mass Fire Experiments, J. of Fire Prot. Engr. 5:67-78.

Quintiere, James G. 1998. Principles of Fire Behavior. Delmar Publishers, Albany, New York.

Rehm, R.G., K.B. McGrattan and H.R. Baum. 2000. Large Eddy Simulation of Flow over a Wooded Building Complex. 3rd International Symposium on Computational Wind Engineering CWE 2000. To appear in special CWE 2000 issue of the Wind and Structures Journal.

Rothermel, Richard C. 1972. A Mathematical Model for Predicting Fire Spread in Wildland Fuels. USDA Forest Service Research Paper INT-115, Intermountain Forest and Range Experiment Station.

Rothermel, Richard C. 1983. How to Predict the Spread and Intensity of Forest and Range Fires. U.S. Intermountain Forest and Range Experiment Station, Ogden, UT, Report PB 83-242289.

Stroup, D.W., L. DeLauter. J. Lee and G. Roadarmel. 1999. Scotch Pine Christmas Tree Fire Tests. NIST Report of Test FR 4010.

Tewarson, A. and R.F. Pion. 1999. Flammability of Furnishings. Comb. and Flame 26:85-103.

Trelles, Javier. 1995. Mass Fire Modeling of the 20 October 1991 Oakland Hills Fire. Ph.D. Thesis in Mechanical Engineering, University of California at Berkeley. 
Trelles, Javier, and Patrick J. Pagni. 1997. Fire-Induced Winds in the 20 October 1991 Oakland Hills Fire. Fire Safety Science - Proceedings of the Fifth International Symposium, 3-7 March 1997, Melbourne, Australia, Yuji Hasemi, Editor. 911-922.

Williams, Forman A. 1982. Urban and Wildland Fire Phenomenology. Prog. Energy Combust. Sci. 8:317-354.

Woycheese, J.P. and P.J. Pagni. 1999. Combustion Models for Wooden Brands. Proc. 3rd International Conference on Fire Research and Engineering. 4-8 Oct. Soc. Fire Protect. Engs. Bethesda, MD. 53-71.

Woycheese, J.P., P.J. Pagni and D. Liepmann. 1999. Brand Propagation from Large-Scale Fires. $J$. of Fire Prot. Engr. 10:32-44. 